\title{
Value Relevance, Earnings Management, and Related Party Transactions
}

\author{
Doli Martua Nasution ${ }^{1}$, Aria Farah Mita ${ }^{2 *}$ \\ ${ }^{1}$ Bank Indonesia, Jakarta 10010, Indonesia \\ ${ }^{2}$ Faculty of Economics and Business, Universitas Indonesia, Depok 16424, Indonesia \\ *aria.farahmita@ui.ac.id
}

\begin{abstract}
This study investigates whether abnormal related party transactions as a proxy of earnings management reduce the value relevance of earnings announcements. Based on a sample of firms listed on the Indonesia Stock Exchange from 2010 through 2014, this study documents that listed firms in Indonesia conduct commercial transactions as a regular daily transaction with subsidiaries and affiliated firms which contribute to the firm's reported earnings. This study finds that related party transactions are efficient and do not reduce the value relevance of earnings.
\end{abstract}

Keywords: Related party transactions; Abnormal Related Party Transactions; Value Relevance.

\section{INTRODUCTION}

Recently, the issue of value relevance has received great attention from managers and investors. Managers have the responsibility for maintaining sustainable earnings growth, since their position and compensation are related to the financial figures disclosed in the firm's financial statement. On the other hand, analysts provide useful and reliable information in order to achieve profitable investing decisions. The term "value relevance" here is the ability of financial statements to summarize valuable information that affects stock price movements and helps investors to determine the value of the firm.

Indonesia, a developing country which has recently attracted considerable attention for its growth rate and better transparency of the government and firms, has a unique ownership structure. Most firms in Indonesia are owned by certain families, meaning that that the majority shareholders are concentrated as controlling shareholders, or are owned by the government. Listed firms in Indonesia are mostly controlled by family owners, who usually appoint family members as key management personnel. These families tend to have more than one firm as a complete supply chain. These firms are established to support each other in order to lead the market, to reduce the cost of the final product.

Firms engaged in related party transactions to perform earnings management in order to smooth the firms' financial statements ${ }^{1,2}$. Some firms undertake related party transactions with the intention of performing earnings management, while others do not. In order to support its corporate actions in the near future, this intention to perform earnings management may influence the firm's stock price. Value investors who rely only on the fundamental value of the firm sometimes make unprofitable investment decisions based solely on financial statements that have been influenced by earnings management. Earnings management reduces the value relevance of the accounting information published by listed firms ${ }^{3}$.

The remainder of the study proceeds as follows. Section 2 presents the hypothesis development. Sections 3 presents the research methods, and data and empirical results follow in Section 4. Finally, the last section provides the conclusions.

\section{LITERATURE REVIEW AND HYPOTHESIS DEVELOPMENT}

The quality of financial statements depends on the full disclosure of firms' transactions. Earnings management is the action of management to employ the accounting policy in order to present information regarding firms' performance in accordance with management's interests. Related party transactions with the intention of doing earnings management affected the quality of firms' financial statements ${ }^{1,4,5}$. Numbers presented in financial statements are in line with the market perceptions, as shown by the firms' stock price. Accounting information has value relevance when it influences the stock price and stock return ${ }^{6,7}$. The quality of accounting information is correlated with earnings management and value relevance ${ }^{8-10}$.

The higher the quality of information, the higher the value relevance of the book value and market value of the equity, because every change, whether it is an increase or a decrease in the numbers presented in financial statements, should affect investors' decisions. However, earnings management behavior will decrease the value relevance of earnings announcements. In this study, earnings management is proxied by abnormal related party transactions. Abnormal related party transactions that indicate earnings management behavior will distort the value relevance of the earnings announcement. Thus, the hypothesis is: 
H1: Abnormal related party transactions reduce the value relevance of earnings

\section{RESEARCH METHOD}

This study adopts Shan's model ${ }^{3}$ to test the effect of earnings management on value relevance. Shan ${ }^{3}$ employs abnormal related party transactions as a proxy of earnings management. To estimate the abnormal related party transactions, the following model is used:

$$
R L P T_{i, t}=\alpha+\beta_{1} L E V E R A G E_{i, t}+\beta_{2} \operatorname{FIRMSIZE}_{i, t}+\beta_{3} M K V E_{i, t}+\varepsilon_{i, t}
$$

The residual value of the regression is deemed as the abnormal related party transactions in which firms engaged in earnings management. RLPT is related party transactions disclosed in the firms' financial statements. LEVERAGE is the result of total liabilities divided by total assets. FIRMSIZE is the natural log of total assets, in which total assets represent the ability of the firms to generate more profit in the future. MKVE is the market value of equity divided by the book value of equity.

Furthermore, the Ohlson Model is used to test the value relevance ${ }^{3,11-13}$. Stock price is the closing stock price on April $30^{\text {th }}$. The following is the model used to test the hypothesis:

$$
P R I C E_{i t}^{A P R I L}=f\left(B V P S_{i t}, E P S_{i t}, A B N R P T_{i t}, E P S_{i t} * A B N R P T_{i t}\right)
$$

PRICE is the stock price. BVPS is book value per share as the result of total equity divided by total outstanding shares. EPS is earning per share. ABNRPT is abnormal related party transactions as a proxy of earnings management. This study employs the balanced panel to test the hypotheses.

\section{RESULTS AND DISCUSSION}

This study employs published financial statements of firms listed on the Indonesia Stock Exchange over the period 2010-2014. Financial companies and companies that use currencies other than Indonesian Rupiahs are excluded from the sample. Since balanced panels are employed, firms with incomplete data, such as firms listed after 2010 or those that were delisted over the 2010-2014 period are eliminated from the sample. Firms that do not engage and do not disclose any related party transactions over the period 2010-2014 are excluded. The sample consists of 193 of the 504 firms listed in the Indonesia Stock Exchange. Details of the sample selection are as

Table.1. Sample Selection

\begin{tabular}{lc}
\hline Total number of listed firms till 2014 & 504 \\
Less: & Financial services \\
IPO after 2010 & $(132)$ \\
Reporting currency other than IDR & $(75)$ \\
Not engage in related party transactions & $(78)$ \\
Selected samples & $(26)$ \\
\hline
\end{tabular}

The following are the descriptive statistics of the variables employed in the hypotheses:

Table.2. Descriptive Statistics

\begin{tabular}{lrr}
\hline Variable & \multicolumn{1}{c}{ Mean } & \multicolumn{1}{c}{ Std. Dev. } \\
\hline ABNRPT & $-25.100 .000,00$ & $9.630 .000 .000 .000,00$ \\
PRICE & $2.492,43$ & $6.858,70$ \\
BVPS & $3.143,11$ & $6.604,57$ \\
EPS & 103,16 & 729,42 \\
\hline
\end{tabular}

Based on Table 2, the average value of ABNRPT is negative, which means that data used in the observation of related party transactions conducted by firms listed on the Indonesia Stock Exchange have the intention of decreasing income.

The results of the regression to test the hypothesis are presented in Table 3:

Table.3. Hypotheses Testing

\begin{tabular}{lrrrl}
\hline \multirow{2}{*}{ PRICE } & \multicolumn{1}{c}{ Coef. } & \multicolumn{1}{c}{ Std. } & \multicolumn{1}{c}{$\mathrm{Z}$} & $\mathrm{P}>[\mathrm{z}]$ \\
\hline Cons & $1.470,00$ & 457,354 & 3,220 & 0,001 \\
BVPS & 0,302 & 0,467 & 6,480 & $0,000^{* * *}$ \\
EPS & $-0,078$ & 0,231 & $-0,340$ & 0,734 \\
ABNRPT & $-2,95 \times 10^{-10}$ & $1,34 \times 10^{-10}$ & $-2,200$ & $0,028^{* *}$ \\
EPS* & $2 \times 10^{-13}$ & $1 \times 10^{-13}$ & 2,400 & $0,016^{* *}$ \\
\hline
\end{tabular}




\begin{tabular}{lc}
\hline ABNRPT & \\
R-square \\
Prob $>$ & 0,1667 \\
chi2 & 0,000 \\
\hline
\end{tabular}

Table 3 shows that the variable ABNRPT is negative and significant at $\alpha=5 \%$, which represents a negative significant correlation between ABNRPT and PRICE. This negative correlation indicates that companies with high abnormal related party transactions have lower stock prices.

EPS*ABNRPT as an interaction variable between EPS and ABNRPT has a positive and significant coefficient, which means the higher the abnormal related party transactions, the higher the value relevance of EPS. This result indicates that investors respond positively to firms' earnings which are associated with abnormal related party transactions.

Nevertheless, the total effect of the abnormal related party transactions (see the total coefficient of ABNRPT and EPS*ABNRPT) is negative on stock price. The more the firm engages in abnormal related party transactions, the lower the stock price. BVPS has a positive and significant coefficient, which means that the book value has value relevance.

\section{CONCLUSION}

Based on the regression result, abnormal related party transactions are not an indicator of earnings management by listed firms in Indonesia. The related party transactions have a positive association with value relevance of earnings. A firm's engagement in higher abnormal related party transactions does not reduce the value relevance of earnings. This result is not consistent with $\mathrm{Shan}^{3}$.

This study finds that investors view the related party transactions as efficient for the company. This may be because the larger the companies and the more varied their line of business, the more opportunity and ability they might have to conduct abnormal volumes of related party transactions. These transactions are common practice by controlling shareholders in Indonesia. For instance, by acquiring targeted firms that produce raw material, the firm might lower the cost of its products or might even get a better rating to acquire new loans through subsidiaries. Most of the big market capitalization firms in Indonesia have a complete supply chain for their products. Sometimes, the subsidiary conducts transactions solely with the parent company. They do this as normal practice to lead the market, which is aligned with shareholders' interest.

\section{REFERENCES}

[1] M. Jian, T. J. Wong. Propping through Related Party Transactions. Review of Accounting Studies, 15(1)(2010) 70-105.

[2] R. M. K. Wong, J. B. Kim, A. W. Y. Lo. Are related party sales value adding or value destroying? Evidence from China. Journal of International Financial Management and Accounting, 16(1)(2015) 1-3.

[3] Y. G. Shan. Value relevance, earnings management and corporate governance in China. Emerging Market Review, 23(2015) $186-207$.

[4] A. W. Y. Lo, R. M. K. Wong. An empirical study of voluntary transfer pricing disclosures in China. Journal of Accounting and Public Policy, 30(6)(2011) 607-628.

[5] Y. G. Shan. Corporate governance and voluntary disclosure of related party transactions in China. Proceedings of the 37th Annual Congress of European Accounting Association, Estonian Business School, University of Tartu, Tallinn, Estonia, (2014) 21-23.

[6] Barth, M. E., Beaver, W. H., Landsman, W. R. The relevance of the value-relevance literature for financial accounting standard setting: another view, Journal of Accounting and Economics, 31(1-3) (2001) 77-104.

[7] R. W. Holthausen, R. L. Watts. The relevance of the value relevance literature for financial accounting standard setting. Journal of Accounting and Economics, 31(1-3)(2001) 3-75.

[8] M. Lang, J. S. Raedy, W. Wilson. Earnings management and cross listing: are reconciled earnings comparable to US earnings? Journal of Accounting and Economics, 42(1/2)(2006) 255-283.

[9] M. E. Barth, W. R. Landsman, M. H. Lang. International accounting standards and accounting quality. Journal of Accounting Research, 46(3)(2008) 467-498.

[10] M. Pananen, H. Lin. The development of accounting quality of IAS and IFRS overtime: the case of Germany. Journal of International Accounting Research, 8(1)(2009) 31-55.

[11] Z. J. Lin., F. Chen. Value relevance of international accounting standards harmonization: evidence from A- and B-share markets in China. Journal of International Accounting, Auditing and Taxation, 14(2)(2005) 79-103.

[12] J. Liu, C. Liu. Value relevance of accounting information in different stock market segments the case of Chinese A-, B-, and H-shares. Journal of International Accounting Research, 6(2)(2007) 55-81.

[13] W. Ge, D. H. Drury, S. Fortin, F. Liu, and D. Tsang. Value relevance of disclosed related party transactions. Advances in Accounting, incorporating Advances in International Accounting, 26(1)(2010) 134-141. 